\title{
The long-term effects of climatic factors on radial growth of downy birch (Betula pubescens) and rowan (Sorbus aucuparia) in East Iceland
}

\author{
Nandini HanNaK ${ }^{1}$ and Ólafur Eggertsson ${ }^{2}$ \\ ${ }^{1}$ University of Sustainable Development Eberswalde (HNE), Germany. Nandini Hannak, nandini.hannak@gmail.com \\ ${ }^{2}$ Icelandic Forest Research, Mógilsá, 162 Reykjavik, Iceland. E-mail: olie@skogur.is (corresponding author)
}

\begin{abstract}
The aim of this study was to investigate the tree-ring growth of rowan (Sorbus aucuparia L.) and downy birch (Betula pubescens Ehrh.) in Ranaskógur, a forest in East Iceland, and to determine its response to climate factors during the past century. Tree-core samples were collected in September 2018 and from those a tree-ring width (TRW) chronology and a standardized tree-ring index (TRI) chronology were produced. A statistical analysis between the chronologies and monthly mean temperatures and total monthly precipitation was carried out. The study found that both species had similar radial growth during the past century. The growth of birch responded significantly positively to June and July temperatures, while rowan responded significantly positively to July and August temperatures. The growth of neither species was significantly affected by precipitation across the whole period. However, in the 1940s to early 1960s, rowan growth correlated significantly with June precipitation, and birch with April and May precipitation.
\end{abstract}

Keywords: Dendrochronology, Tree-rings, Forest ecology, Native forest, Insects, Hallormsstadur.

\section{YFIRLIT}

Áhrif umhverfispátta á árlegan vöxt (árhringjabreiddir) ilmbjarkar (Betula pubescens) og reyniviðar (Sorbus aucuparia) á Austurlandi.

Markmið pessarar rannsóknar var að kanna árhringjavöxt reyniviðar (Sorbus aucuparia L.) og birkis (Betula pubescens Ehrh.) í Ranaskógi á Austurlandi og svörun hans við veðurfarsveiflum síðustu aldar. Borkjarnasýnum var safnað í september 2018. Árhringjabreiddirnar voru mældar upp og búið til meðalárhringjatímatal fyrir báðar trjátegundirnar. Árhringjatímatölin voru síðan tölfræðilega borin saman við meðalmánaðarhita og úrkomu nærliggjandi veðurstöðva. Niðurstöður sýndu að fylgni árhringjavaxtar beggja trjátegunda var allmennt há alla síðustu öld. Hitafar í júní og júlí gaf góða jákvæða fylgni við árhringjavöxt birkis en reyniviðurinn hafði hæstu jákvæðu fylgnina við hitafar í júlí og ágúst. Lítil fylgni var við úrkomu hjá báðum tegundunum yfir allt tímabilið, en samt mátti greina marktæka fylgni við úrkomu í júní fyrir reyniviðinn í apríl og maí hjá birkinu á fimmta og sjötta áratug síðustu aldar pegar trén voru yngri.

\section{INTRODUCTION}

The forest cover in Iceland is predominantly composed of natural forests of downy birch (Betula pubescens Ehrh.). Though there are other tree species native to Iceland, they are far less common than birch, and there are few to no natural forests which are not largely or entirely composed of birch. Rowan (Sorbus aucuparia L.) is one such tree species, which, 
while native to Iceland, is uncommon and rarely found growing in the wild (Blöndal 2000). Rowan trees can be found in birch forests and woodlands across the country, but there are few forests where they occur in large numbers (Blöndal 2000).

Ranaskógur is a privately owned forest located close to the Hallormsstaður National Forest in East Iceland (Figure 1). The area around Hallormsstaður and Ranaskógur has been continuously covered by forest since possibly before the settlement of Iceland in the late ninth century, making it one of the oldest forests in the country (Hallgrímsson 1989). Ranaskógur itself is also famous for its old, tall birch trees as well as its large number of mature rowan trees. Similar natural forest stands as Ranaskógur are rare both in Iceland and abroad. Therefore, it is important to study the interaction between the two species and their growth response to environmental parameters, e.g. temperature and precipitation .
The aim of this study was to investigate the past growth of rowan and birch trees in Ranaskógur to see how the radial growth of the two species compares. The objectives were to produce tree-ring chronologies of rowan and birch in Ranaskógur, to compare the treering growth of both species, and to determine and compare how the two species respond to temperature and precipitation. Past tree-ring studies in Iceland found that tree-ring growth of birch in Iceland is mainly influenced by summer temperature (June-August) and by pests (e.g. insect outbreaks), while rowan is mainly influenced by summer temperature (Levanic \& Eggertsson 2008, Pórarinsson \& Eggertsson 2012, Eggertsson 2014, Kaczka et al. 2015, Piermattei et al. 2017). Studies on the annual growth of birch in Northern Norway found similar influences of summer temperature as in Iceland (Opala et al. 2016). Building on this, the present study looked at the response of tree-

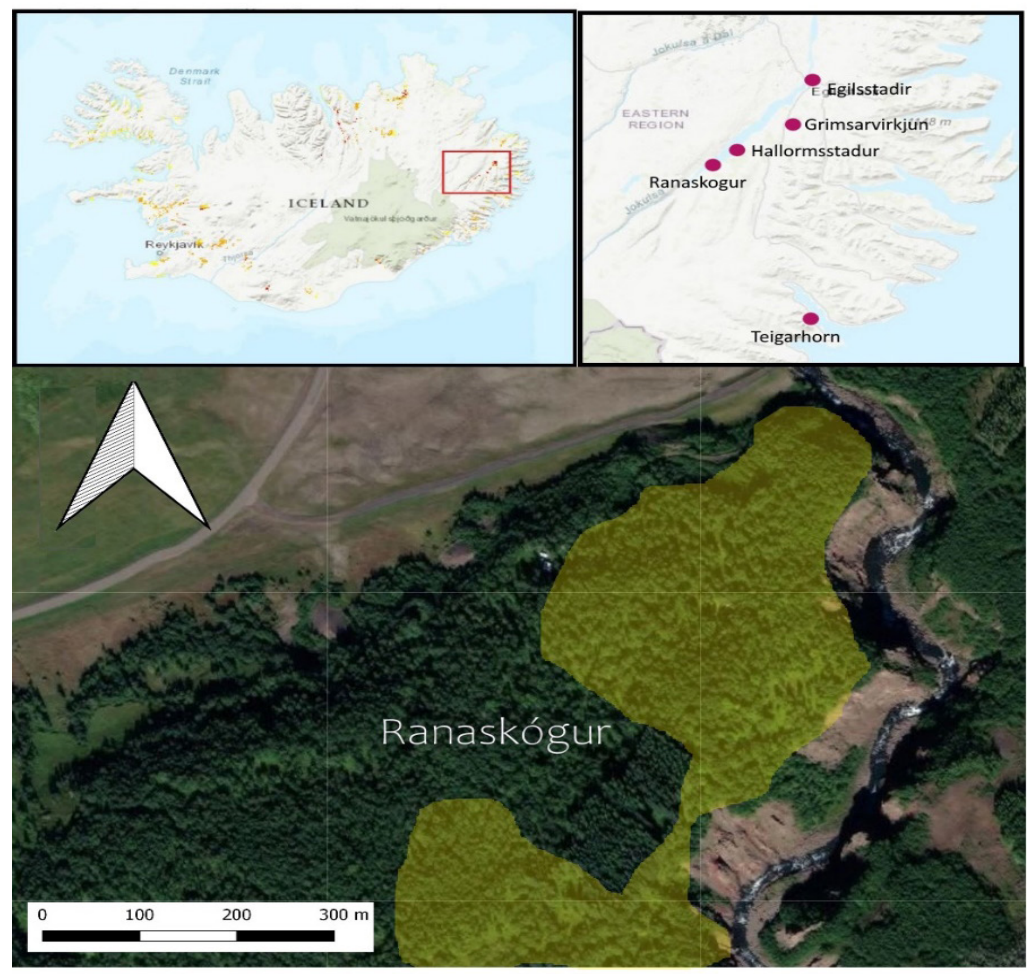

Figure 1. Location of Ranaskógur and IMO weather stations (Hallormsstaður, Grimsarvirkjun, Egilsstaðir, Teigarhorn) in East Iceland. Map of sampling sites (light green) of birch and rowan. (Produced with QGIS 2.14, 2019. Base Map: iceforestservice.maps.arcgis.com.is). 
ring growth to summer temperature as well as to temperature and precipitation in all months of the year.

\section{MATERIALS AND METHODS}

Core samples were collected from downy birch and rowan in Ranaskógur $\left(65^{\circ} 03.83^{\prime}\right.$ $\mathrm{N}, 14^{\circ} 50.20^{\prime} \mathrm{W}$; ca. $80 \mathrm{~m}$ above sea level) in September 2018 (Figure 1). The measurement and analysis of the samples was then carried out at the Icelandic Forest Research, Mógilsá.

A total of 15 rowan trees and 26 birch trees were sampled. Two core samples were taken from each tree at a height of 0.50 meters (m), using a Haglöf Increment Borer. Samples were taken at a height of $0.50 \mathrm{~m}$ as many of the birch trees had low branches which made it impossible to take samples from higher up on the trunk. The rowan trees were sampled at the same height, to ensure consistency in the sampling method. The height of each tree was measured with a Haglöf EC-II Electronic Clinometer, with an accuracy of \pm 1 meter.

In the lab, the core samples were dried and prepared. The samples were measured using a Rinntech LINTAB measuring system in conjunction with the software TSAPWin (Rinn 2003). The tree-ring widths were measured in millimeters $(\mathrm{mm})$ with an accuracy of one micrometer $(1 / 1000 \mathrm{~mm})$. The measurement was carried out starting from the pith or the innermost ring, measuring outwards towards the bark. A tree-ring width series was produced from each core sample.

The crossdating of the tree-ring series was carried out in two parts: a visual comparison of the series in the form of line graphs in TSAPWin, and statistical comparison in COFECHA to verify the accuracy of the visual crossdating (Speer 2010). The visual crossdating of the birch series was conducted with the additional aid of a master chronology from birch trees in the Hallormsstaður National Forest, circa 4-6 $\mathrm{km}$ away (Eggertsson 2014). Following the crossdating, series with little to no correlation were remeasured or otherwise removed from the study sample. A total of 18 birch tree series and 27 rowan core series were produced.
A tree-ring width (TRW) chronology was produced for both species, from the core series of rowan and the tree series of birch. By averaging multiple tree series, to produce a chronology, the noise or signal of factors which affect year-to-year growth of an individual tree (e.g. competition or age), was removed or reduced, while the shared signal of factors that affect all trees in the area (e.g. climate or outbreak of pests) becomes clearer (Briffa \& Jones 1990). The TRW chronologies were produced in TSAPWin. A transformation function was applied to set the mean of all tree series to center around $0.1 \mathrm{~mm}$. Mean annual tree-ring growth was determined to produce a TRW chronology. Since the transformation function was applied, the TRW chronologies do not show the average annual ring width but instead relative ring width.

To ensure that the stand-level signal was representative and not too greatly distorted by the growth of individual trees, a minimum significant sample size of five trees was chosen. Years in which the TRW chronology consisted of less than five trees were omitted. Though the birch TRW chronology consisted of only 3-4 birch trees from 2003 onwards, the years 20032017 were not cut from the birch series. These years were included because in 2003-2017 the birch trees correlated strongly with each other as well as with the rowan chronology, Eggertsson's Hallormsstaður birch chronology, and monthly temperature. The TRW chronology of rowan covers 1907 to 2017 and the birch chronology covers 1900-2017.

Tree-ring index (TRI) chronologies were produced for both species in COFECHA. Before importing the rowan core series and birch tree series into COFECHA, the series were cropped so as to have a minimum significant sample size of five trees. The birch series were cropped so as not to include tree-rings before 1900, while tree-rings before 1907 were cut from the rowan series. With COFECHA, the autocorrelation of each series was removed, and a 32-year cubic smoothing spline applied to generate an agegrowth curve from the series. Using the growth curve, the program automatically removes the age trend and calculates the growth indices. 
Growth indices show how much a tree grew in one year in relation to its growth during all other years (Speer 2010). Through standardization the age-trend of individual trees and autocorrelation were removed to ensure that the chronology contained a clear stand-level signal (GrissinoMayer 2001). A master dating series, the TRI chronology, was produced for either species by taking the average of the index series of all trees.

\section{Data Analysis}

The approximate age of each tree was determined using the dated tree series produced in TSAPWin. The age of the tree is taken to be equal to the number of tree-rings between the pith and the outer most ring, plus 2 years (assumed to be roughly the time needed for the trees to reach a height of $0.5 \mathrm{~m}$ ). If the pith was not visible in the core sample, the number of rings between the innermost ring and pith was estimated.

Pointer years, years in which most trees in an area have significantly wider or narrower tree-rings, were identified using the $\mathrm{R}$ package pointRes and the "relative growth change" method (van der Maaten-Theunissen, et.al. 2015). The relative growth change function (pointer.rgc) calculates mean growth deviation. In this way it identifies years in which $75 \%$ or more of the TRW tree series have a significant growth deviation (narrower/wider tree-rings) relative to the tree-ring width in previous and subsequent years. The individual unstandardized TRW series of birch and rowan were used for this.

Outliers of the TRI chronologies of birch and rowan were determined using Microsoft Office Excel. The upper and lower quartile and interquartile range (IQR) of the index values were calculated to determine the upper and lower bounds, and the logical function was applied to determine the outliers, i.e. the years the index values fell outside of the lower or upper bounds. Outliers were determined relative to the growth in all years.

Comparison of Birch and Rowan Chronologies The TRW and TRI chronologies of rowan and birch were compared visually as line graphs.
The Pearson correlation coefficient was calculated for the correlation between the TRI of the two species, for the period 1907 to 2017. The year 2018 was disregarded as the samples had been taken in that year. The correlation was also calculated in 30-year windows to identify periods in which the correlation between the growth of rowan and birch was significantly higher or lower. An independent or unpaired two-sample t-test, with 95\% significance level, was conducted to determine if the correlation was significant.

\section{Tree Growth and Climate}

The climate data used in this study were taken from the Icelandic Meteorological Office (IMO, 2019). Hallormsstaður is the closest weather station to Ranaskógur (ca. $8 \mathrm{~km}$ away). Thus, temperature and precipitation readings from this station were assumed to be most representative of the actual conditions at Ranaskógur.

Temperature readings for Hallormsstaður are available from 1942 onwards. In years in which temperature data were missing, 198993 and 1996, data were taken from the station at Egilsstaðir (ca. $35 \mathrm{~km}$ away). Temperature readings from the two stations were similar, with a strong correlation between mean annual temperature (correlation coefficient $=0.99$ ) and mean summer (June-August) temperature $(=0.98)$ (Figure 2).

Precipitation data for Hallormsstaður are available from 1942 to 1989 and 2014 to 2017. Precipitation data from Grímsárvirkjun (ca. $17 \mathrm{~km}$ away) were used for the missing years. This station only records precipitation, not temperature. Monthly precipitation at Grímsárvirkjun is more similar to Hallormsstaður ( $=0.82-0.97)$ than Egilsstaðir $(=0.25-0.82)$.

Additionally, tree growth was compared with temperature data from Teigarhorn. This station was included in the study as it has one of the longest, continuous temperature series in Iceland, from 1873 onwards. Teigarhorn is located further from Ranaskógur and is directly by the sea, so temperature recorded 


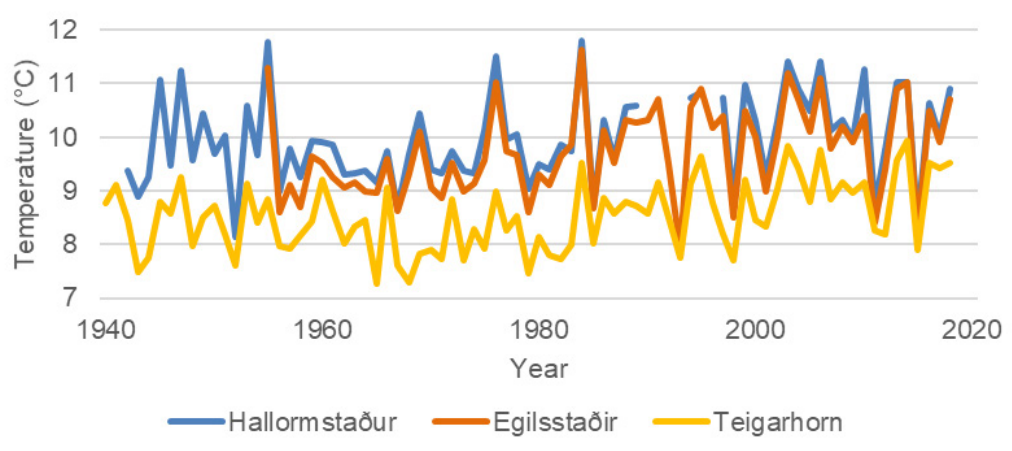

Figure 2. Comparison of the mean summer temperature (June-August) between the stations Hallormsstaður, Egilsstaðir and Teigarhorn, 1940-2018, data from IMO, Veðurstofa Íslands (2019). at Teigarhorn was considered to be less representative for Ranaskógur. The correlation between annual mean temperature of Teigarhorn and Hallormsstaður or Egilsstaðir stations was high (correlation coefficient 0.95-0.96), but the correlation between summer mean temperature was lower (0.72-0.76), and the summer temperature at Teigarhorn was on average 0.5 to $2^{\circ} \mathrm{C}$ cooler (Figure 2 ).

\section{Comparing Tree-Ring Growth and Climate Variables}

Tree-ring growth and climate were compared using the climate variables, mean monthly temperature and total monthly precipitation. These are the standard climate variables used in dendrochronological studies (Zang \& Biondi 2015).

Using the $\mathrm{R}$ package, treeclim, a response function analysis of the TRI chronologies of rowan and birch and mean monthly temperature was developed, and total monthly precipitation was conducted for both tree species for the period 1942-2017 (Zang \& Biondi 2015). The response function determines the correlation between growth and temperature or precipitation per month, and compares the correlation of each month of a year or selected period, to determine the "effective climate window", the months in which tree-ring growth had the greatest response to the climate variable (Briffa \& Cook 1990, Fritts 2001, Speer 2010). Tree-ring growth was compared with the precipitation and temperature over a 12-month period, from October of the previous year to September of the current year. Based on the results of the response analysis, boxplots were generated, to show the mean response coefficients and the range of response coefficients for the relationship between the tree indices and the temperature and precipitation of each month.

Further, a correlation analysis with moving windows was conducted. The moving windows analysis calculates the correlation between the tree indices and the temperature or precipitation data of each month for consecutive windows (Zang \& Biondi 2015). The analysis was conducted using 30-year windows with 1-year offset. The month range, previous October to current September, was used.

The Pearson correlation coefficient of the correlation between tree-ring growth and summer temperature (June, July and August) was calculated for 1942-2017, in 30-year windows. Mean summer temperature was calculated by taking the average of the monthly temperature in June, July and August in Hallormsstaður of each year. An unpaired two-sample t-test was conducted, with 95\% significance level, to determine whether the calculated correlations were significant. Line graphs were generated to compare the birch and rowan TRI chronologies and summer temperature at Hallormsstaður.

The response function analysis and correlation analysis with moving windows was also conducted with temperature data from Teigarhorn for 1907-2017. No analysis was conducted with precipitation from Teigarhorn due to missing data and a low correlation with Hallormsstaður. 


\section{RESULTS}

Age and height

As of September 2018, the sampled birch trees were between 88 to 126 years old; the mean age was 113 . The rowan trees were 83 to 141 years old, with mean age 109. The birch trees were between 5 to $12 \mathrm{~m}$ tall, and the rowan trees 7 to $13 \mathrm{~m}$ tall. Aside from recent regeneration $(\leq 1 \mathrm{~m})$, no rowan shorter than $7 \mathrm{~m}$ were found in the sample area. A simple linear regression analysis was conducted but no significant relationship between age and height was found for either birch $\left(R^{2}=0.06\right)$ or for rowan $\left(R^{2}=-0.27\right.$; data not shown).

\section{TRW Series of Rowan and Downy Birch}

The TRW chronologies of birch and rowan for the period 1900-2018 are shown in Figure 3. A basic overview and descriptive statistics of the unstandardized TRW series of birch and rowan are given in Table 1. A strong series

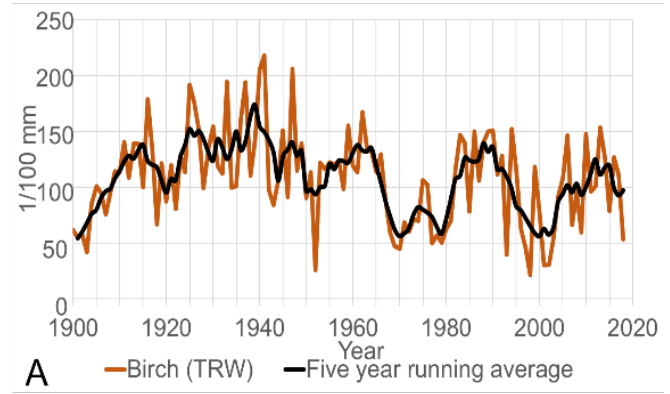

intercorrelation was determined for both tree species, indicating a reliable stand signal. The mean sensitivity of the rowan series was lower than that of birch. The standardized birch TRW chronology covered 119 years, from 1900 to 2018 (Figure 3A), with only three trees predating 1900. The rowan chronology coveeds 112 years, from 1907 to 2018 (Figure 3B ).

Comparing the TRI chronologies of Rowan and Downy Birch

The TRI chronologies of rowan and birch were compared for the period 1907 to 2017 (Figure 4 ), and a significant correlation was determined (Pearson $\mathrm{R}=0.57$ ). The correlation was significant and positive in all 30 -year windows. The correlation was greatest in the windows 1978-2008 and 1985-2015 (both =0.72). The lowest correlation was in 1953-1983 $(=0.35)$. The correlation of the two species was highest in the consecutive windows 1974-2004 to 1987-

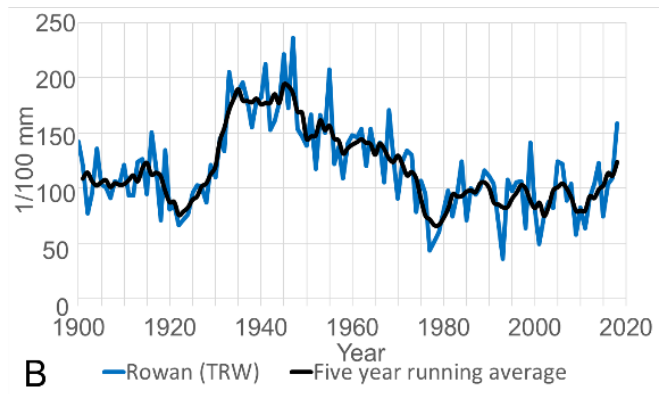

Figure 3. The average tree-ring width chronologies (1900-2018) (TRW) for downy birch (A) and rowan (B) from Ranaskógur, East Iceland. The ring width is given in 1/100 of a mm. The black lines show the five-year running mean.

Table 1. Basic summary and descriptive statistics of the TRW master chronology for downy birch and rowan from Ranaskógur, East Iceland.

\begin{tabular}{lll}
\hline Statistical parameters & Downy Birch & Rowan \\
\hline Length of chronology & 119 years (1900-2018) & 112 years (1907-2018) \\
Number of trees & 26 & 15 \\
TRW Series intercorrelation & 0.743 & 0.749 \\
Average mean sensitivity & 0.442 & 0.321 \\
Mean autocorrelation & 0.454 & 0.679 \\
Mean ring width & $0.95 \mathrm{~mm}$ & $0.98 \mathrm{~mm}$ \\
Longest tree-ring series & 124 years $(1894-2018)$ & 138 years $(1880-2018)$ \\
\hline
\end{tabular}




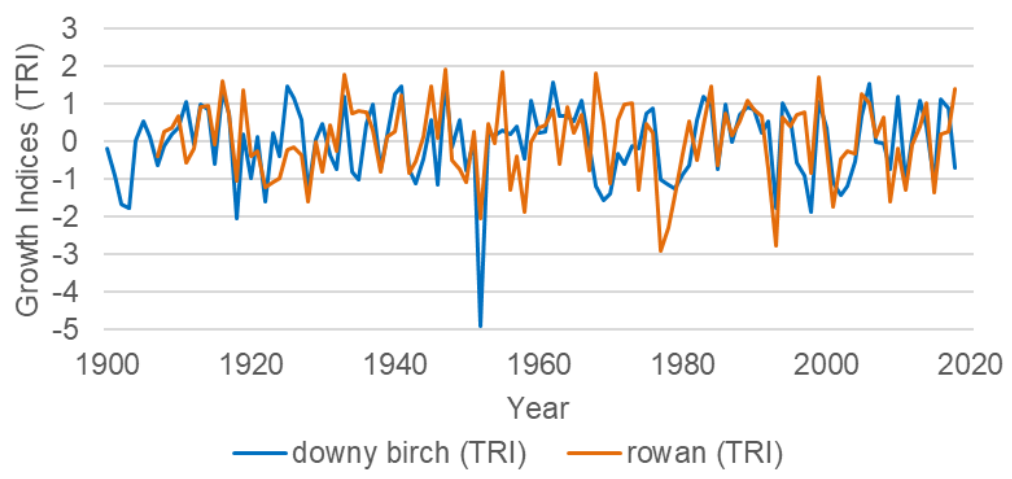

Figure 4. Tree-ring index (TRI) chronologies of downy birch and rowan from Ranaskógur.

2017 (=0.67-0.72) and lowest from 1942-1972 to $1962-1992(=0.35-0.47)$. The plotted lines showed that the TRI chronologies overlapped most in the first 15 years and last 30 years (Figure 4). The plotted lines differed most in 1926-27, 1934-35, 1952, 1955, 1968-69 and 1977 .

\section{Mean Monthly Temperature and Growth (TRI)}

The boxplot in Figure 5 shows the mean response coefficient of mean monthly temperature and the growth of birch. From 1942 to 2017 the growth of birch in Ranaskógur showed a significant positive response to mean monthly temperature in June $(=0.40)$ and July $(=0.23)$, as recorded in Hallormsstaður. No significant response was determined for any other month.

Figure 6 shows the correlation between growth of birch and monthly temperature in 30-year windows, from 1942 to 2017. A significant, continuous positive correlation
(=0.23-0.52) was found with July, though it was not significant in all windows. From the window 1971-2000 onwards, a significant, strong positive correlation $(=0.56-0.63)$ between growth and June temperature was found. Before this window, the correlation was not significant, and from 1950-1979 to 1956-1985 growth and temperature did not correlate at all. A significant positive correlation was determined for February 1953-1982 to $1959-1988$ (=0.43-0.50).

Through the response function analysis of growth of rowan and mean monthly temperature at Hallormsstaður 1942-2017 (Figure 7), it was found that radial growth of rowan showed a significant positive response to the temperature of July ( $=0.41)$ and August ( $=0.25)$. No significant response was determined for any other month. The moving windows analysis (Figure 8) showed that a consistently significant positive correlation $(=0.39-0.74) \quad$ existed between growth and temperature in July in all windows.

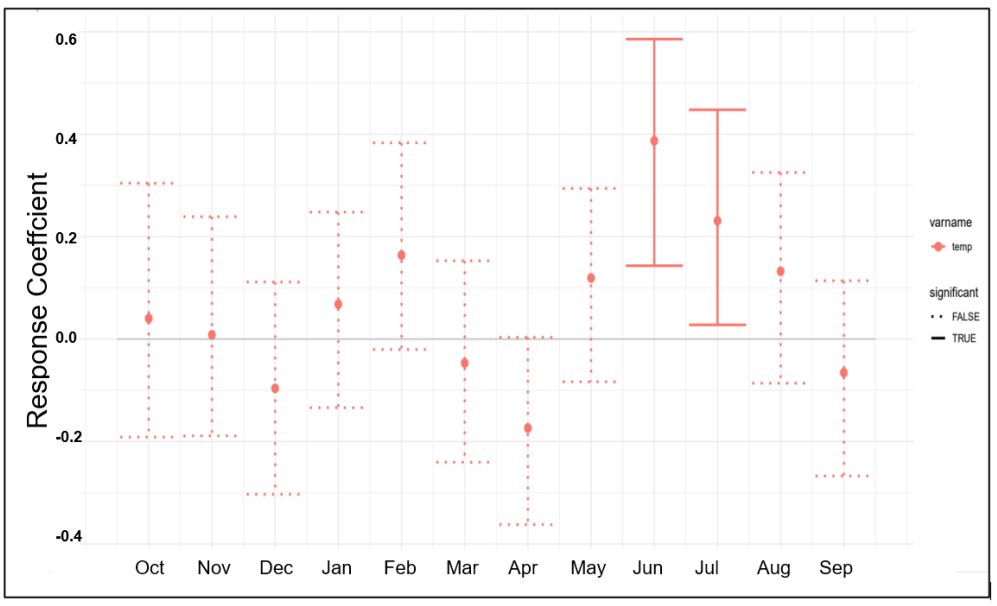

Figure 5. The response coefficient of the relationship between the tree-ring index (TRI) of downy birch in Ranaskógur and the mean monthly temperature $\left({ }^{\circ} \mathrm{C}\right)$ of Hallormsstaður, 1942-2017. A significant correlation $(\mathrm{p}<0.05)$ is shown by a solid line. 

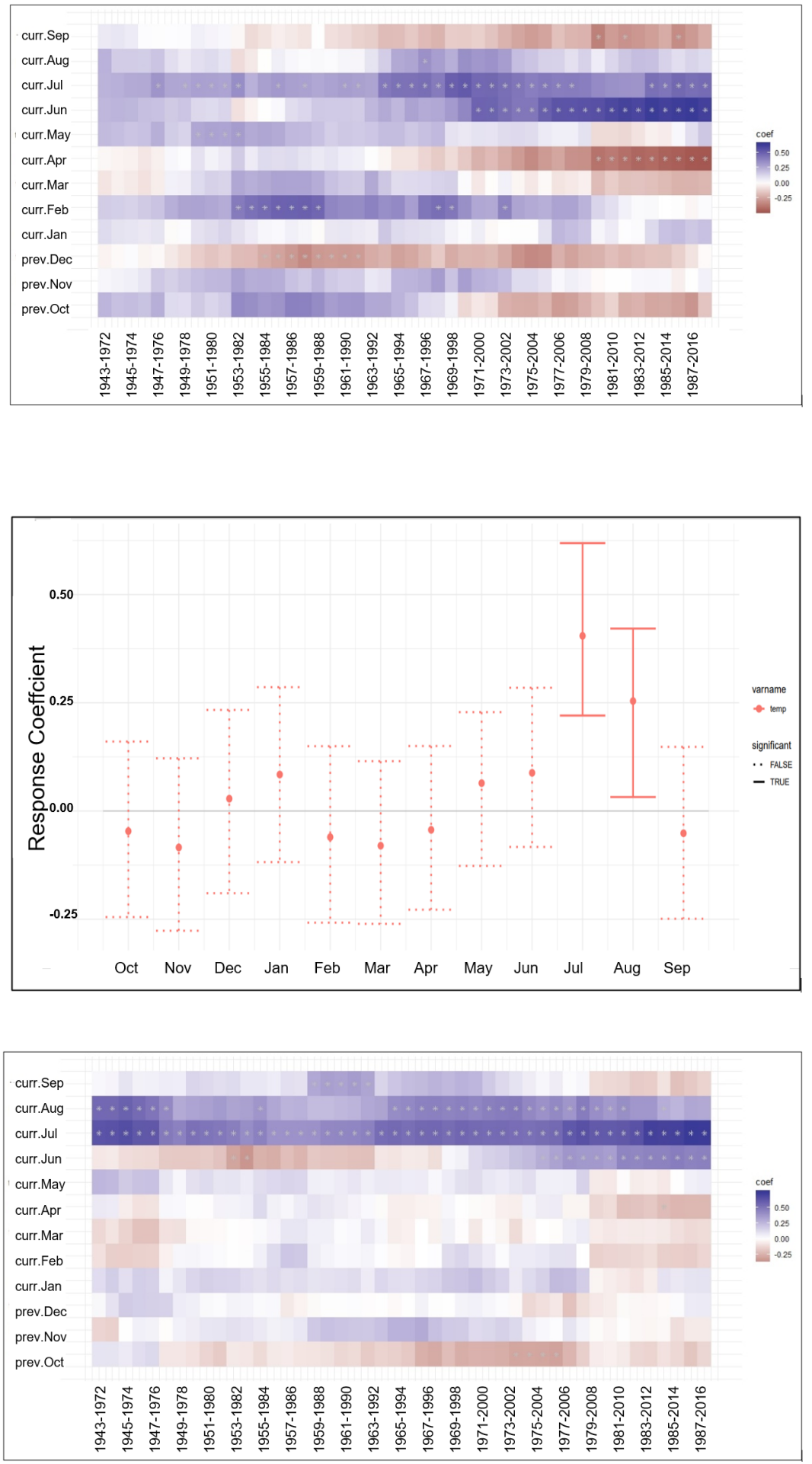

Figure 6. Correlation analysis with moving time windows (30-year windows) of the correlation between the tree-ring index (TRI) of downy birch in Ranaskógur and the mean monthly temperature $\left({ }^{\circ} \mathrm{C}\right)$ at Hallormsstaður, 1942-2017. An asterisk $\left.{ }^{*}\right)$ denotes a significant correlation $(\mathrm{p}<0.05)$.

Figure 7. The response coefficient of the relationship between the tree-ring index (TRI) of rowan in Ranaskógur and the mean monthly temperature $\left({ }^{\circ} \mathrm{C}\right)$ of Hallormsstaður, 19422017. A significant correlation $(\mathrm{p}<0.05)$ is denoted by a solid line.

Figure 8. Correlation analysis with moving time windows (30-year windows) of the correlation between the tree-ring index (TRI) of rowan in Ranaskógur and the mean monthly temperature $\left({ }^{\circ} \mathrm{C}\right)$ at Hallormsstaður, 19422017. An asterisk (*) denotes a significant correlation $(\mathrm{p}<0.05)$. 
The growth of rowan correlated strongly with August ( $=0.27-0.58)$ from 1942 to 2017 , but the correlation was not significant in all widows. A significant positive correlation was also found between growth and mean temperature in June in the windows 1976-2005 onwards (=0.29-0.46), and September from 1959-1988 to 1963-1992 (=0.29-0.35). A significant negative correlation was found between growth and temperature in October of the previous year from 1973-2002 to 1977-2006 (=-0.27-0.31).

\section{Summer Temperature and Growth (TRI)}

Significant positive correlations were found between summer temperature and growth of birch $(=0.53)$, and rowan $(=0.59)$ in 19422017. As shown in Figure 9, the correlation of rowan and birch with summer temperature was positive and significant for all 30-year windows except 1953-1983 to 1962-1992, when the correlation was lower or not significant. In 1953-1983 to 1956-1986 both rowan and birch correlated less with summer temperature, but the correlation was not similarly low. In 19571987 to $1962-1992$ the correlation coefficients of rowan and birch were similar. From 19621992 onwards the correlation of both species increased continuously. The summer mean temperature increased on average by $0.7^{\circ} \mathrm{C}$ and the mean monthly temperature of June, July and August increased by around $0.7,0.3$, and $0.9^{\circ} \mathrm{C}$, respectively, between 1942 to 2017 .

Additional correlation analyses were carried out to compare rowan with the mean temperature of July-August, and birch with the

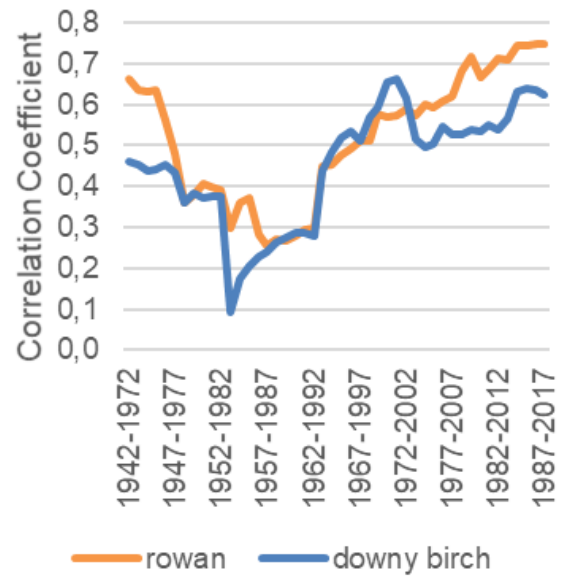

Figure 9. Pearson Correlation coefficient (R) of the correlation in 30-year windows of the TRI of rowan (orange) and the TRI of birch (blue) with mean summer temperature $\left({ }^{\circ} \mathrm{C}\right.$, June-August). The correlations were not significant in 1953-1983 to 1962-1992.

mean temperature of June-July. Birch correlated strongly with the mean temperature of JuneJuly ( $=0.59)$, though the correlation was not significant in the windows 1953-1983 to 19571987. The correlation between rowan and the mean for July-August was as strong $(=0.59)$ as the correlation with June-August. On average the mean temperature of June-July was $0.7^{\circ} \mathrm{C}$ cooler than the mean temperature of JulyAugust .

Figure 10 compares the TRI chronology of birch and the mean temperature of June-July. The plotted lines matched least between 1950 to 1980, while the greatest overlap was from 1980

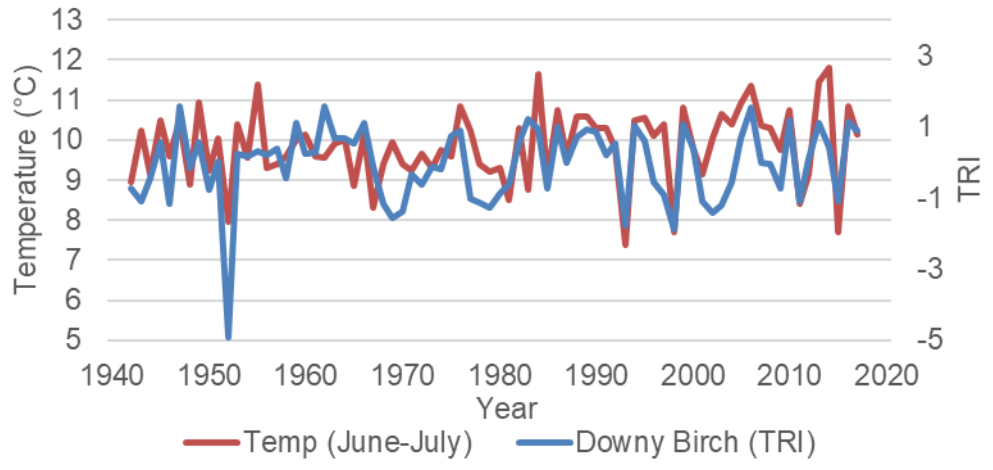

Figure 10. Tree-ring index (TRI) chronology of birch from Ranaskógur (1940-2018) and average temperature for June and July from Hallormsstaður (1942-2018). Growth correlated significantly with mean temperature of JuneJuly $(r=0.59)$. 


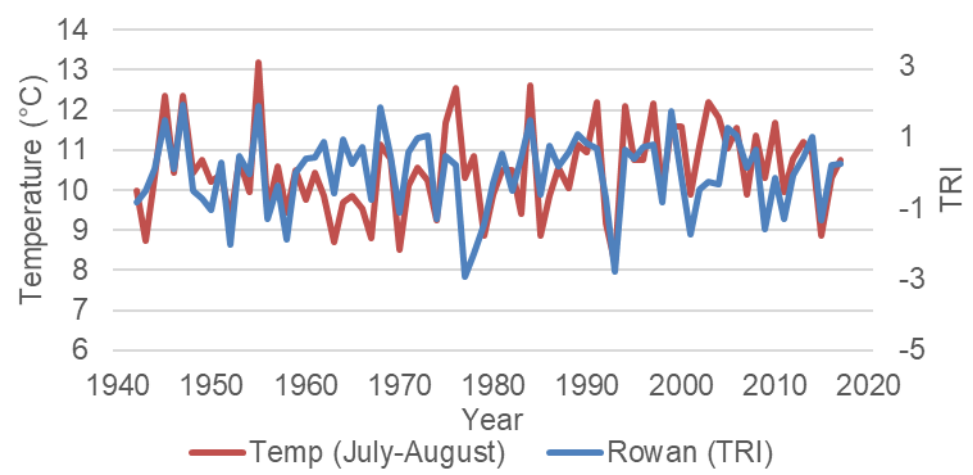

Figure 11. Tree-ring index (TRI) chronology of rowan from Ranaskógur (19402018) and average temperature for July and August from Hallormsstaður (1942-2018). Growth correlated significantly with mean temperature of JulyAugust ( $\mathrm{r}=0.58)$. to 2017 . In $1952,1955,1969-1970,1977$, and 2002-2003 the plotted lines differed most. In these years, growth was disproportionately low, compared to temperature. The growth in 1955 did not appear to correlate with or respond to the warm summer. The rowan TRI chronology and mean temperature of July-August were compared visually as well (Figure 11). The plotted lines matched most from 1944 to 1959 and matched relatively well from 1982 to 2017 . The years with noticeably little to no correlation were 1977 and 2003.

The response function analysis using temperatures from Teigarhorn for 1907-2017 found that birch responded positively to temperatures in June $(=0.26)$, July $(=0.16)$, and August $(=0.16)$. Rowan responded positively to temperatures in July $(=0.18)$ and August $(=0.21)$. Both birch and rowan responded negatively to temperatures in April $(=-0.20$, -0.22 ). The moving windows analysis found that the correlation of rowan with August temperatures was the only correlation that remained significant throughout 1907-2017.

\section{Precipitation and Tree-Ring Growth Indices}

The response function analysis found that there was no significant response of treering growth for either tree species to total monthly precipitation at Hallormsstaður, 19422017. When the response function analysis was run using only precipitation data from Hallormsstaður (1942-1989), a significant positive response of rowan to June precipitation $(=0.30)$, and birch to May precipitation $(=0.20)$ was determined (figure not shown).

Figure 12 shows the correlation between growth of birch and total monthly precipitation in 30-year windows for 1942-2017. In the earlier years, birch correlated positively with April and May, and negatively with January. The correlation with either month was not

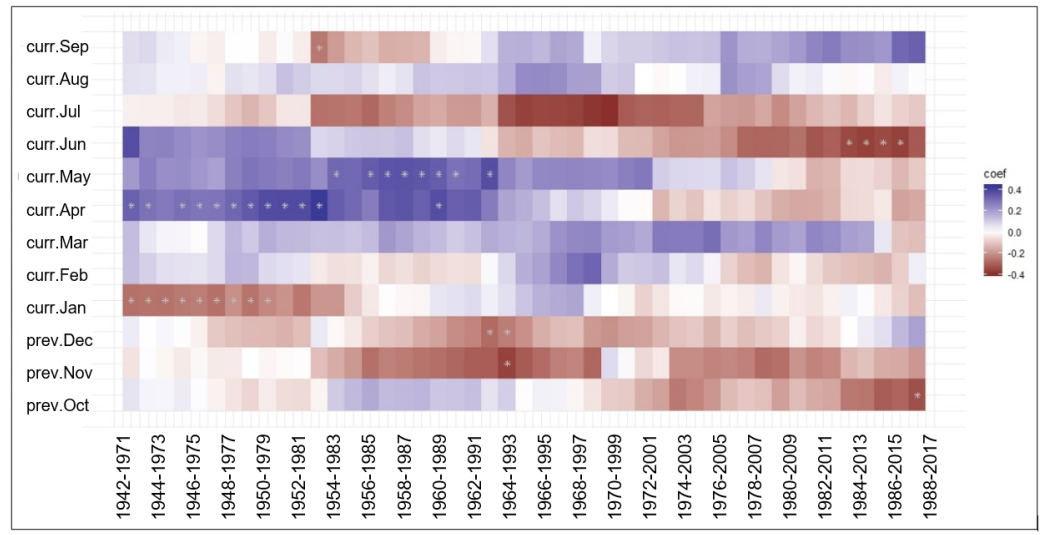

Figure 12. Correlation analysis with moving time windows (30-year windows) of the correlation between the tree-ring index (TRI) of downy birch in Ranaskógur and the total monthly precipitation $(\mathrm{mm})$ in Hallormsstaður, 1942-2017. An asterisk (*) denotes a significant correlation. 


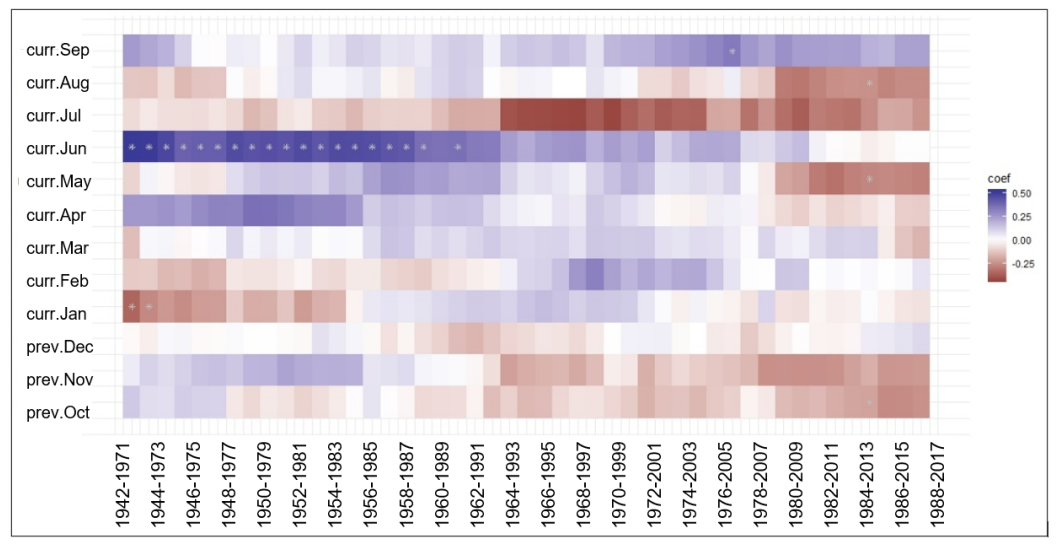

Figure 13. Correlation analysis with moving time windows (30-year windows) of the correlation between the tree-ring index (TRI) of rowan in Ranaskógur and the total monthly precipitation $(\mathrm{mm})$ in Hallormsstaður, 1942-2017. An asterisk (*) denotes a significant correlation.

significant for all windows, and in later windows the correlation was low or negative.

A significant positive correlation $(=0.35$ 0.50) was determined between the growth of rowan and June precipitation from 1942-1971 to 1961-1990 (Figure 13). From 1961-1990 onwards the correlation gradually decreased and was not significant.

\section{Pointer Years and Outliers}

The negative pointer years of the birch TRW series were 1900-1902, 1952, 1993, 1998 and 2002-2003. The year 1983 was the only positive pointer year. The negative pointer years of the rowan series were 1977, 1993 and 2001. Pointer years of the birch series before 1900 and after 2003 were disregarded.

There were outliers in the TRI chronology of rowan in 1977 and 1993. In these years the growth was significantly lower. The only outlier of birch was in 1952, with significantly lower growth. The only outlier or pointer year the two tree species had in common was 1993. Rowan had fewer pointer years and more outliers than birch.

The negative pointer years 1902, 1952, 1993 and 1998 coincided with years with cold summer temperature, as measured at Hallormsstaður and Teigarhorn. Some of the coldest summers in Hallormsstaður in the last century were in 1952, 1993 and 1998. The coldest summer, with the lowest mean monthly temperature in July, was in 1993. The second coldest summer was 1952 , with the coldest mean June temperature. The temperatures in June and July in 1998 were low, whereas the temperature in August was average to warm. The year 1902 had one of the coldest summers recorded at Teigarhorn.

The year 1977 was a negative pointer year for rowan. In this year, the total monthly precipitation in May, June and July was low, and it was one of the driest years in Hallormsstaður. The year 2002 was a negative pointer year of birch and it was one of the wettest years; the rainfall in May and April in 2002 was higher than in any other year.

\section{DISCUSSION}

\section{Temperature and Radial Growth}

As determined through the response and correlation analysis, the radial growth of birch and rowan in Ranaskógur responded significantly positively to summer temperature. While birch responded most to the temperature in early summer (June-July mean), rowan correlated equally strongly with June-August and July-August but responded most to July and August temperatures. It would appear that the growth period of birch and rowan in Ranaskógur was June-July and July-August, respectively.

The correlation between summer temperature (June-August) and radial growth of birch in Ranaskógur $(=0.53)$ was similar to that of birch in Hallormsstaður $(=0.48)$ (Eggertsson 2014). However, Eggertsson found that the temperature of July rather than June had the 


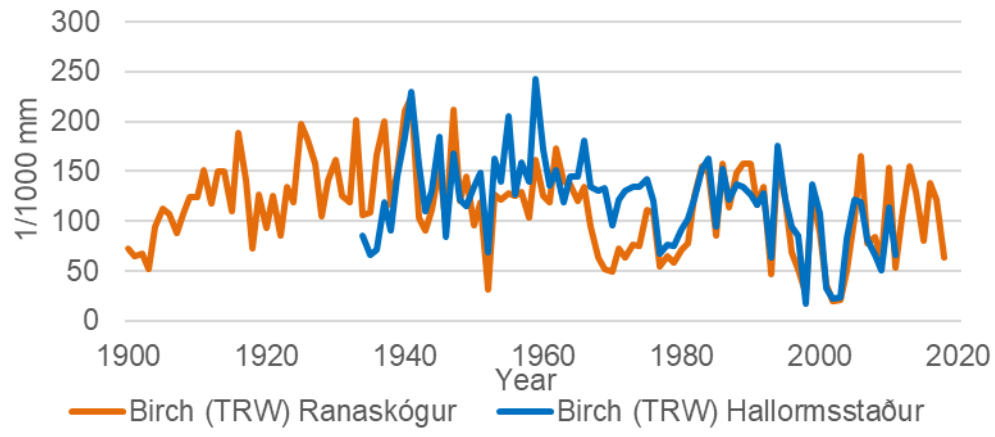

Figure 14. Tree-ring width (TRW) chronologies of downy birch from Ranaskógur and published TRW data from Hallormsstaður from Eggertsson (2014).

The tree-ring pattern of the two chronologies was quite similar. greatest effect $(=0.42)$ on radial growth of birch in Hallormsstaður. Similarly, Piermattei et al. (2017) found that birch trees were most affected by July temperatures, with May, July and August being the months with the greatest effect on growth of rowan and birch sampled in East and Southeast Iceland. In Ranaskógur, birch growth responded most to June temperature $(=0.40)$; however the correlation with June temperatures was only significant in later years (Figure 6). In contrast, the response of birch growth to July temperatures was weaker but significant for a longer period, for windows 1946-1975 to 19882017 (Figure 6). Possibly the correlation with June was significant and stronger in recent years due to radial growth responding to the warmer June temperatures. As stated in the results, the June temperatures at Hallormsstaður in recent years were warmer.

The radial growth of birch and rowan over the last century was significantly similar and both species responded strongly to summer temperatures. Yet, the correlations and responses were stronger in recent years while weaker or not significant in earlier years, particularly from circa 1950 to 1980. Birch did not correlate significantly with June and correlated less with July temperatures in the windows 1942-1974 to 1962-1991 (Figure 6). Similarly, radial growth of rowan correlated less with the mean monthly temperature of August in the period 1948-1977 to 1965-1994 (Figures 8). As shown in Figure 9, both rowan and birch did not correlate significantly with summer temperatures in 1953-1983 to 1962-
1992. Furthermore, as seen in Figure 4, the TRI chronologies of birch and rowan matched less in 1950 to 1980 . It would appear that temperature had less effect on growth or that factors or conditions other than temperature had a greater effect in these years. Whatever the cause of the low correlation of growth with temperature, it did not affect rowan and birch in the same way, given the low correlation of the two species in this period. As shown in Figure 14, from 1952 to 1975 the birch chronologies from Ranaskógur and Hallormsstaður (Eggertsson 2013) also had a lower visual overlap. Whatever affected birch and rowan in Ranaskógur in this period appears to have been local or site-specific, as it does not appear to have affected the birch in Hallormsstaður .

Birch trees in Ranaskógur, unlike rowan, appear to have been more sensitive to winter temperatures. In later years, 1980-2009 to 1988-2017, growth correlated negatively with April temperatures (Figure 6). April was not noticeably warmer or colder in this period. In earlier years, 1953-1982 to 1959-1988, birch growth correlated positively with February temperatures (Figure 6). In East Iceland, the coldest month was typically February (Einarsson 1984). The coldest February temperatures recorded at Hallormsstaður between 1942-2017 were in 1955, 1958, 1966 and 1968-1970. While none of these years were negative pointer years of birch, it appears that February temperatures had a significant effect on the radial growth of birch in these years. Whether this was linked to the low correlation between rowan and birch 
and between birch and summer temperatures between 1950 to 1980 is not certain.

\section{Precipitation and Radial Growth}

Birch and rowan growth did not respond significantly to precipitation in the period 1942-2017. However, in 1942-1989, rowan responded significantly to June precipitation, and birch responded significantly to May and correlated positively with April and May, but negatively with January (Figures 12 and 13). In East Iceland May and June are generally the driest months (Einarsson 1984). It would appear that in 1942-1989 the radial growth of birch and rowan was affected by the precipitation of the driest months and/or the month(s) preceding the growth period, (June-July and July-August, respectively). Birch growth also seems to have been sensitive to a wetter January in this period.

It is possible that the response of rowan and birch to precipitation was not significant after 1989, because precipitation had less effect on radial growth after 1989. Alternatively, it is possible that the precipitation data from Grímsárvirkjun used to replace missing data from Hallormsstaður in 1990-2013 was not representative of actual precipitation at Ranaskógur, resulting in a lower correlation in this period.

Overall, the significant response determined for 1942-1989 is somewhat questionable, given that this is a relatively short time frame (47 years) to build on, in comparison to 1942-2017 (75 years). Further, Piermattei et al. (2017) found that there is little to no correlation of radial growth of birch and rowan with precipitation in Iceland. Either precipitation had a greater effect on radial growth in this period, possibly causing the lower correlation of growth with temperature in the 1950 s to 1980 s, or the correlation with precipitation in this period is a coincidence and not indicative of an actual growth response.

Overall, the radial growth of birch in Ranaskógur appears to have been more sensitive or responsive to climate factors than rowan. Alternatively, birch growth was affected more by other factors, so that the response of rowan to temperature and precipitation appeared clearer. As seen in the moving correlation analysis
(Figures 8 and 13), rowan did not correlate with any other month other than July and August temperatures and June precipitation. Further the correlation with these months was significant throughout 1942 to 2017 or was otherwise continuous and significant for longer periods.

\section{Pointer years}

In Ranaskógur, most of the pointer years identified were years in which the summer temperature was cold and significantly below average. This was the case with the pointer years of rowan, 1993 and 2001, and the pointer years of birch, 1902, 1952, 1993 and 1998. A study of birch in Northern Iceland, found that negative pointer years occurred in years in which the summers were cooler and the winter dry (Levanic \& Eggertsson 2008). This seems to have been the case for birch and rowan in Ranaskógur as well. However, it was found that certain pointer years of birch matched years in which outbreaks of moth larvae occurred on birch in Hallormsstaðaskógur.

Major, widespread outbreaks occurred in 1934-35, 1952, 1977, 1998 and 2001-2006 (Annual Reports of Forestry Officer in East Iceland) (Halldórsson et.al 2013). While no outbreaks in Ranaskógur were reported, it is probable that, given the proximity of Hallormsstaður, larvae would have also occurred on birch in Ranaskógur during major outbreaks. Intense defoliation through outbreaks would explain why 1952, 1998 and 2002-2003 were pointer years or outliers of the birch chronology, and why in 1934-35 and 1977-79 the growth of birch was considerably lower (Figure 4). Furthermore, in 1952 the growth of rowan was not significantly low, while the growth of birch was lowest in this year. In 1952, and possibly 1998 as well, birch may have been affected by both the cold summer and defoliation. However, it is possible that the growth of birch was much lower than that of rowan in 1952 and 1998 as only the early summer (June-July) of these years was cold, while August was average or warm. The pointer year 2002 may also have been due to the high rainfall in spring, rather than due to an outbreak. Overall, it is uncertain whether or 
not outbreaks occurred on birch in Ranaskógur.

The spring and summer of 1977 were very dry, and while birch growth was lower that year, the growth of rowan was the lowest ever between 1907-2017. Possibly, rowan was affected more by lack of precipitation than birch. However, rowan growth was not significantly lower in any other year with low spring and summer rainfall.

\section{CONCLUSION}

The study was successful in producing treering chronologies of downy birch and rowan in Ranaskógur. Using the chronologies, the treering growth of the two species was compared, and the response of both species to temperature and precipitation was determined. The study found that the tree-ring growth of both species in the last century was similar, and that both birch and rowan responded significantly to summer temperatures.

While the study was successful in producing master chronologies and in determining the response of growth to temperature, aspects of the study could be improved. A limitation of the study was the small sample size and sample area. In addition, all the trees sampled were older and of similar age. Due to this, it is possible that the growth trend and climate signals in the birch and rowan TRI chronology were affected by the age trend, especially in the later years of the chronology. In future research, it would be advantageous to take core samples from more rowan trees and from younger rowan and birch trees in Ranaskógur and elsewhere in East Iceland. The TRW growth of birch in Ranaskógur and in Hallormsstaður (Eggertsson 2014) were found to be similar (Figure 14). By combining these chronologies, and sampling rowan and birch elsewhere in East Iceland, master chronologies of rowan and birch could be produced for the whole of East Iceland. Such master chronologies would make it easier to date tree-ring series, and in addition would allow greater insight into past radial growth and the relationship of growth and climate. By taking samples from outside Ranaskógur, it could also be determined which signals are due to regional factors or due to site factors at Ranaskógur.
Another improvement to the method in the future would be to focus further on climate extremes (i.e. extreme heat or frost or drought) rather than climate averages, and to study what effect these have had on radial growth of birch and rowan.

\section{ACKNOWLEDGEMENTS}

We would like to express thanks to Sigurður Kjerulf, the owner of Ranaskógur, who kindly gave permission and license to sample trees in the forest stand.

\section{REFERENCES}

Annual Reports of Forestry Officer in East Iceland. Annual Forestry Reports, Austurland. Accessed June $2019<$ https://www.skogur.is/is/umskograektina/utgefid-efni/arsskyrslur-skogarvarda/ austurland>

Blöndal S 2000. Reyniviður (Sorbus aucuparia L.) á Íslandi. [Rowan (Sorbus aucuparia L.) in Iceland]. Skógrcektarritið 2000 (1), 17-48. [In Icelandic].

Briffa K \& Cook E 1990. Methods of response function analysis. In: Cook ER, Kairiukstis LA (eds) Methods of Dendrochronology, Applications in the Environmental Sciences. Kluwer Academic Publishers, Dordrecht, 240-247.

Briffa K \& Jones PD 1990. Basic chronology statistics and assessment. In: Cook ER, Kairiukstis LA (eds) Methods of Dendrochronology, Applications in the Environmental Sciences. Kluwer Academic Publishers, Dordrecht, 136-152.

Eggertsson Ó 2014. Vöxtur Birkis á Hallormsstað árin 1950-2011 og tengsl vid Veðurfar og Maðkaá. [The Growth of Downy Birch in Hallormsstaður 1950-2011 and the relationship between climate and insect outbreaks]. Ársrit Skógrcektar Ríkisins 2013, 52-53. [In Icelandic].

Einarsson MÁ 1984. Climate of Iceland. In: Van Loon, H. World Survey of Climatology: 15: Climates of the Oceans. Ed. H. van Loon. Vol. 15. Amsterdam: Elsevier, 673-697.

Fritts $\mathrm{H}$ 2001. Tree Rings and Climate. Caldwell, NJ: Blackburn Press.

Grissino-Mayer HD 2001. Evaluating crossdating accuracy, A manual and tutorial for the computer program cofecha. Tree-Ring Research 57(2), 205221. 
Halldórsson G, Sigurðsson BD, Hrafnkelsdóttir B, Oddsdóttir ES, Eggertsson Ó \& Ólafsson E 2013. New arthropod herbivores on trees and shrubs in Iceland and changes in pest dynamics: A review. Icelandic Agricultural Sciences 26, 69-84.

Hallgrímsson H 1989. Úr sögu Ranaskógur í Fljótsdal. [History of Ranaskógur in Fljótsdal]. Ársrit Skógrcektarfélags Íslands 1989, 19-32. [In Icelandic].

IMO, Icelandic Meteorological Office 2019. Mean monthly data for Egilsstaðir, Hallormsstaður, and Teigarhorn. Climatological Data. Icelandic Meteorological Office [In Icelandic], Accessed 01.10.2019 at < https://www.vedur.is/vedur/ vedurfar/medaltalstoflur/ $>$.

Kaczka RJ, Janecka K, Czajka B \& Eggertsson Ó 2015. The tree ring study of Downy birch in Northern Europe. TRACE - Tree Rings in Archaeology, Climatology and Ecology, Scientific Technical Report STR15/16, Vol. 13, GFZ Potsdam, Potsdam, 96-100

Levanic $\mathbf{T}$ \& Eggertsson $O$ 2008. Climatic effects on birch (Betula pubescens Ehrh.) growth in Fnjoskadalur valley, northern Iceland. Dendrochronologia 25, 135-143.

https://doi.org/10.1016/j.dendro.2006.12.001

Opala M, Migala K \& Owczarek P 2016. Two centuries-long dendroclimatic reconstruction based on Low Arctic Betula pubescens from Tromsø Region, Northern Norway. Polish Polar Research. 37 (4), 457-476.

https://doi: 10.1515/popore-2016-0024

Piermattei A, Urbinati, Tonelli CE, Eggertsson Ó, Levanic T, Kaczka RJ, Andrew C, Schöne BR \& Büntgen U 2017. Potential and limitation of combining terrestrial and marine growth records from Iceland. Global and Planetary Change 155, 213-224. https://doi: 10.1016/j.gloplacha.2017.07.010

Rinn F 2003. TSAP-Win - Time Series Analysis and Presentation Dendrochronology and Related Applications, Heidelberg.

Speer JH 2010. Fundamentals of Tree Ring Research, The University of Arizona Press, Tucson.

Pórarinsson SJ \& Eggertsson Ó 2012. Vistfræði reyniviðar (Sorbus aucuparia L.) í Trostansfirði. [The ecology of Rowan (Sorbus aucuparia L.) in Trostansfjörður]. Skógrcektarritið 2012 (1), 47-54. [In Icelandic]. van der Maaten-Theunissen M., van der Maaten E. \& Bouriaud O. 2015. pointRes: An R package to analyze pointer years and components of resilience. Dendrochronologia 35: 34-38.

https://doi.org/10.1016/j.dendro.2015.05.006

Zang C \& Biondi F 2015. Treeclim, an R package for the numerical calibration of proxy-climate relationships. Ecography 38(4), 431-436.

https://doi.org/10.1111/ecog.01335

Manuscript received 20.5.2020

Accepted 11.9.2020 